\title{
Vico and Modern Thought: A Pedagogical Proposal
}

\author{
Domenico Pietropaolo
}

Today more than ever it is incumbent upon us to show the contemporary relevance of what we teach. We live in an age of hic et munc, an age in which the centrality of the present has crossed the boundaries of metaphysical speculation to become the basis of everyone's self-understanding. In the vast majority of cases, programme formation and selection in our universities is determined solely by the practical demands of future careers, while course material is appreciated only in proportion to its potential contribution to a chosen area of concentration, understood as the essential core of one's education. And at a more advances level, professional scholars read widely in fields adjacent to theirs, gleaning concepts, methods, and models that they can bring to bear on the object of their direct research in order to enrich their understanding of it. Students want to know how relevant a given course is to their professional orientation and how useful it can be to them as researchers in their discipline of specialization. Why, indeed, teach Vico today in North America? Of what relevance is his thought to North American students of the 1990's? What can they learn from Vico that can better enable them to face their professional tasks as humanists of the modern world? How can Vico speak to them and be heard across the distance of space and history?

In spite of the unprecedented and still increasing domestication of Vico studies in North America inaugurated by the tradition-setting International Symposium of 1969 (Tagliacozzo and White), which celebrated the beginning of the fourth century of Vico's life in history, brief selections from his works are no more than a small component of North-American anthological courses in liberal arts and in Italian literature, while, to my knowledge, monographic graduate courses on his thought-such as the one that I have been regularly offering since 1983 at the University of Toronto-are still very rare.' However, there can be no doubt that, whereas he has not yet succeeded in obtaining the space that he merits in our classrooms - which are naturally and understandably reluctant to grant institutional sanction to challenging innovations - Vico is nevertheless conquering America in the scholarly literature. Benedetto Croce would be surely surprised to find out that, only a few decades after he accused foreign scholars of ignorance for failing to see the importance of Vico in western philosophical history, allusion to Vico's thought is a frequent occurrence in North America, and that some of his most basic teachings would be echoed again and again in the disciplines of 
the future $(8,293-94)$. And the momentum - thanks to the continued efforts the Institute for Vico Studies - is very rapidly increasing. A remarkable number of philologically responsible researchers in the humanities obviously feel the need to come to terms with Vico, in whom they frequently find ideal fatherhood, philosophical allegiance, and stimulation for further growth. ${ }^{2}$

It is in this literature - and not in the history of philosophy or in traditional Vico scholarship - that most graduate students first encounter the name of Vico, and it is with the expectations raised by such reading that they come to his works. Those students are as heterogeneous a group as their colleagues in other programmes, but they share this feature: they all expect Vico to speak to their major concerns and to provide them with a source of ideas and methods applicable to other areas.

The course that I propose, which is based on the one that I actually offer at the University of Toronto, is an attempt to teach Vico's thought and to meet in part such expectations by using the students' academic background in the interpretation of his works. It is intended to be a systematic effort to let Vico speak to the students through selected aspects of contemporary culture. Its purpose is to explain Vico's philosophy and at once to show its relevance to the modern world without divorcing it from its original historical context. This should not be misconstrued as a way of artificially assimilating Vico to modern thought or of vulgarly instrumentalising him toward the clarification of other disciplines, for it is only an application of the universally acknowledged principle that our understanding of the past cannot be independent of our roots in the present. A great lesson of our times is that an epistemology of total objectivity is logically impossible. Knowledge is recognitive in greater measure than it is cognitive, and to that extent it is a hermeneutical product, necessarily conditioned by the pre-understanding that those who seek it unavoidably bring to it. This is true in all fields, but it is especially consequential in the historical sciences, where man is both the subject and the object of research. To be sure, historical discourse depends principally on its object of investigation and narration, but it is also governed by the peculiar historicity of the researcher and shaped by the literary form in which it is cast. ${ }^{3}$ Though much practical criticism is tacitly and anachronistically anchored to the assumption that the attainment of Rankean objectivity is only methodologically difficult but not logically impossible, theory has taken full cognizance of the consequences of this new conception of historical discourse and has already explored some of its implications for various disciplines.

But first a few technical details. The course on which this proposal is based is offered by the Department of Italian Studies and is available to all graduate students at the University of Toronto with an adequate reading knowledge of Italian, though in the past it has been taken only by students enrolled in Italian literature, Italian linguistics, and comparative literature. Ideally a course on Vico should consist of a total of 52 class hours, distributed in 26 two-hour sessions over two terms. The texts should include the poem 
Affeti di un disperato, selections from the Latin works De nostri temporis studiorum ratione and De antigncissima italorum sapientia, the autobiography, the Ietter to Gherardo degli Angioli on Dante, the posthumous work known as Discoverta del vero Dante, the oration De mente heroica, and the complete text of the Scienza mova of 1744. These works, including those originally in Latin, can be studied in Nicolini's one-volume edition of the Opere' (Ricciardi, 1953); other editions can be consulted in the case of controversial passages or philologically improved readings. The course should be structured as a seminar and should be conducted in Italian. The minor works should be discussed in the first term; the Scienza nuota, in the second. If only one term is available, the course should be restricted to Scienza nuova. The analysis of the textual material in each class should be focused on one (possibly two) of the topics that Vico deals with in that selection; this topic can then be treated as a conceptual centre of gravity for the discussion of less prominent issues and ancillary problems. Because at the University of Toronto the course is offered in the context of a literature programme, issues pertaining to literary theory are consciously highlighted. Furthermore, the privileging of individual issues in class discussions and the actual choice of texts for the entire course necessarily correspond to a general view of Vico and of the task of Vico studies which is intended to condition the perception of his thought that the students will have when they leave the course.

North American students are in general culturally unsuited to pursue training in Vico philology, since in our universities they do not have sufficient access to the propaedeutics and materials of textual criticism in eighteenthcentury Italian programmes and since their coming to Vico is primarily motivated by a need to reach a more rewarding cultural self-understanding. This, on the other hand, makes them better suited than Italian students for a fruitful appropriation of Vico, that is to say for the philosophical reception of his work rather than the historical scansion of his texts. In such a context the history of philosophy, of which Vico comprises an ever morc prominent chapter, makes good pedagogical sense only if we stress the second term of the expression, only if we regard it as a propaedeutic to the analysis of fundamental problems rather than as a species of philology or an archeological introduction to original thinking. But to study the history of philosophy philosophically - which is to study it in a profoundly Vichian manner - is to enter a realm of perpetual contemporaneity and to engage in dialogue with those thinkers who have themselves grappled with issues that still challenge the world of intelligence.

It logically follows from these considerations that a North American monographic course on Vico must have two foci: the text, from which to extract, by historically responsible exegesis, Vico's teaching on a given issue, and the analogous contemporary reflections on which such teaching can be logically brought to bear. The aim is to engage them in reciprocal illumination by letting them in turn assume the roles of explicans and explicandum, so that 
one may come to determinateness in the clarity of the other and vice versa. The pedogogical task is, firstly, to articulate the text's teaching in a manner recognizable to the students as philosophically significant, which is to say in a manner employing the parameters of the chief humanistic debates of our times; and, secondly, to point out how the theoretical concerns that emerge in the spectrum of disciplines which comprise the students' chief interests and background recall Vico, both actually - as an explicit philological point of reference in their self-understanding as areas of inquiry, and as an implicit subtextual presence in their self-elaboration as explanatory theories - and potentially, in the challenge or aid that he can offer to their line of original thinking. The methodological presupposition all throughout is that the real understanding of a text in the present is possible only when the text is allowed to come to life hic et munc, and thereby collaborate with the reader in the pursuit of meaning, which is finally reached-so modern hermeneutics teaches us - when the text's and the reader's distinct cultural horizons come together in mutual integration and reciprocal illumination. ${ }^{4}$

The first effort, therefore, must be to sketch out the text's philosophical horizon in the eighteenth century. Accordingly, 1 structure the first hour of each class along the lines suggested by the first three of the following questions:

(1) In the context of the issue under discussion, what need was there in contemporary philosophy that Vico sought to meet?

The circumscription of this space, on which Vico's thinking came to stand, cannot be accomplished without enlisting the aid of the history of ideas in the European, Italian and Neapolitan perspectives. In order to enable students to face this question meaningfully, the bibliography must be carefully selected for them. The most basic tools, such as the Dictionary of the History of Ideas and the journals devoted to this discipline as well as the chief monographic treatments of key concepts in western intellectual history, frequently lie outside the range of Vico bibliography or else are marginal to it. But for many aspects of Vico's thought there are original and controversial studies along these lines - such as the truly exemplary ones by Gustavo Costa (cf. Pietropaolo 275-77) - which conveniently gather the necessary texts and set them in meaningful relation to the historical and geographical coordinates of Vico's intellectual world. In order to understand some of the most important bibliographical material, however, students must be given sufficient critical orientation, since the delimitation of this space is the subject of an ongoing and influential polemic between, on the one hand, Eugenio Garin, for whom Vico was fully in tune with the intellectual life of the eighteenth century, and, on the other hand, Paolo Rossi and, till his recent death, Arnaldo Momigliano, who maintain the familiar thesis of Vico's isolation from his contemporaries, albeit they see him as being behind his times rather than ahead of them. The purpose of this part of the seminar is therefore twofold: to demarcate the 
space that Vico claimed for his thinking vis-à-1is his contemporaries and to discuss current trenus in Vico scholarship.

(2) What perception did Vico have of his attempt to meet that need?

The answer to this question comprises the basic expository part of the seminar in relation to Vico's self-understanding, as this is revealed to us in the philosophical works themselves as well as in his autobiographical, epistolary and other exegetical references to them. Students are encouraged to become familiar with the specialized bibliography, to seek out and critically consider the theoretical premises of the scholars who have glossed the passages in question, and to present Vico's ideas as answers to questions suggested by the history of the idea under discussion and by the contemporary and quasicontemporary understanding of the same issues. The purpose of the exercise is to articulate the meaning that the texts propose to carry in their own world and thus to complete the picture drawn in the answer to the first question. This means interpreting Vico's ideas in terms of the historico-geographical cultural co-ordinates of the setting in which Vico's thought took shape. The starting point for such an analysis is Nicolini's Commento storico, integrated with the many exegetical articles that have appeared in recent years, especially in connection with the several symposia that have taken place in Europe and in North America since 1968. The attempt to understand Vico in relation to the history of ideas and the cultural debates of his time then leads us to appraise Vico's reflections on other works, distinguishing between the legitimate exegesis - that is, expositions logically unassailable from the historicogeographical perspective described in the first exercise-and the imaginative eisegesis that he rehearsed on the authors against whom he sought conceptual self-definition.

(3) What perception did Vico's early readership have of his view of the philosophical picture of his day?

The purpose of this question is to enable the students to see whether, in the estimation of the philosophical community to which he belonged and from which he constantly sought approval, Vico had the correct understanding of the task of philosophy and was successful in his attempt to carry it out himself. Here more than elsewhere students are in need of bibliographical guidance if they are not to be led astray by the neo-idealistic account of Vico's contemporary reception. As well they are in need of a firm hermeneutical orientation if they are not to regard the study of Vico's contemporary reception as an anachronistic instance of the neopositivist preoccupation with the fortunes of an author. Our purpose is to establish Vico's dialogue with his age, and in this task an adequate knowledge of his reception is of absolutely fundamental significance. The increasing currency that the reader-response hermeneutics of the school of Konstanz enjoys in North America will soon no doubt render most students sensitive to the question of the early reception of any text, but 
at the moment the point must be duly stressed: Vico's reception is our only empirical avenue to the horizon of expectations that surrounded his works upon publication and a verifiable means of assessing Vico's real dialogue with his time. In conjunction with the answers to the first two questions, this account of his reception establishes the purported and actual meanings of Vico in the intellectual life of his day, delimits the ground on which he spoke to his contemporaries, and offers an appraisal of what they heard him say in relation to what he did not or could not say.

The second hour of each class is devoted to the meaning that the text under discussion has or can have in our own cultural context, that is to say in the North American academic milieu of the 1990's. The aim here is not the analytical domination of the text from the vantage point of historical detachment, such as would seek to congeal it in its original philological appearance. Nor is it the subservient reception of its teaching without subjecting it to the challenge of modern perspectives. The aim is rather to let the thinking found in the text come to stand as the reader's dialectical partner in a collaborative examination of the issues at hand. Whereas in the first part of the class the students are anchored to the text - which is considered against its philological and philosophical backgrounds, in its purport and in its reception-here they are encouraged to look at what the text points to when it is allowed to transcend its historicity and to enter the contemporaneity of dialogue. This is articulated in the following four questions:

(4) What categorical apparatus is necessary in order to establish Vico's conceptual link with modern disciplines?

The purpose of this exercise is to warn students that theoretically and empirically unjustifiable associations border on arbitrariness and are the fruit of unrigorous thinking. The pitfall to avoid is the easy category of the "precursor," which brings with it by implication the logically suspect and empirically untenable thesis of Vico's isolation from his contemporaries. The revival of Vico studies that has taken place in the past two decades or so has produced one category capable of vindicating the modernity of his thought without severing it from the milieu in dialogue with which it attained self-articulation, and this is Tagliacozzo's idea of Vico as a "pioneer," understood as a historically conditioned founder of a line of thinking which was sufficient and complete in relations to its age but susceptible of growth and ever greater fruition in later times. ${ }^{5}$ The full categorical implications of this metaphor have not been completely realized by the scholarly community, and consequently even some of the most careful modern reclaimers of Vico have at times slipped into the error of historical anticipation.

(5) In what disciplinary contexts can the aspect of Vico under examination come to life again?

This is a preliminary question, but it is fundamental in the literal sense of the 
word, since it secks to define the cultural space that can recall Vico's thought to presence as a vital force in the evolution of ideas. For the exercise to be meaningful, the disciplines chosen for each class - and they may obviously vary from class to class - must be already familiar to the students, even if in a vague and informal manner. I have found that the principal ones at the University of Toronto are humanism (in Ernesto Grassi's understanding of the term), phenomenological hermeneutics, rhetoric, semiotics, literary theory, psychoanalysis, linguistics and deconstruction. These are areas in which there is no shortage of Vico-related literature; the most recent issues of New I'ico Studies attest to the liveliness of Vico-related research in these and other disciplines and are invaluable tools for the bibliographical organization of this part of the course, as are the systematic Bibliography of Vico in English compiled by Tagliacozzo, Verene and Rumble, and the yearly supplements provided in the journal. This bibliographical material, however, has to be patiently sorted out by the instructor according to the Vichian topics discussed in each class, or else it will not be accessible or useful to most students.

(6) What aspects of the Vichian issue in question can meaningfully retain their original philological form in other disciplinary settings?

The identification of that part of Vico's philosophy which is still meaningful and normative in our own day must begin with those ideas whose current validity or whose implications for modern thought are self-evident. Much work has already been done in the critical literature on Vico and modern thinkers, albeit usually with the hermeneutical purpose of establishing the spiritual filiation of the accepting disciplines rather than the actual vitality of Vico's thought forms vis-à-vis the self-elaboration of those areas of enquiry. But regardless of whether they first encounter the issue in the critical literature or directly in the primary sources in question, students familiar with the basics of the embedding disciplines have no difficulty recognizing the modernity of the principal Vichian ideas that they enclose, since in al] such cases the affinity is revealed either by direct reference or by cognate articulation. To quote three related examples, the verum-factum epistemology as examined from the vantage point of the reader-reception hermeneutics of Hans Robert Jauss (52-54), the concept of sensus communis as analysed in the context of philosophical hermeneutics by Hans Georg Gadamer (19-24), and the principle that in our perception of reality we see projections of our mental structures as found in Mario Valdes elaboration of phenomemological hermeneutics in the sphere of literary studies (5-26) - these ideas do not appear to be in the least incongruous with the taxonomy and thought forms of modern philosophy or to require any cultural translation and adaptation for their proper understanding. The hermeneutical task presupposed in all such cases is simply the interpretation of the Vichian ideas in a manner that respects their context of origin while conferring upon them a centrality which they can manifest only for the embedding theories themselves. Interpretation 
and conferral of centrality are two inseparable phases of understanding as appropriation, which is to say understanding as a drawing into the horizon of the accepting discipline, be it as a concurrent agent or a colliding force. Through this process Vico is explicitly interrogated; his presence in the embedding theory is a record of his contribution to the dialectical search for meaning. But he is also allowed to interrogate: the manner in which the orientation of the ensuing argument depends upon his presence is a record of the theory's response to his challenge.

The chief aim of this hermeneutical analysis of such explicit appropriations of Vichian insights is to show the students that a carefully selected bibliography of Vico related research in the humanities may be for them a resource of suggestions for an analogous treatment of other ideas. The conceptual frameworks that the students inevitably bring to class from other disciplines need no longer be held in check, as they must in the earlier exegetical exercise where they could impede the proper penetration of the text. They may now be allowed to interact creatively with Vico's ideas, interpreting them in terms of their disciplines of origin and, in turn, rearticulating themselves from a Vichian standpoint. As the parameters of the students' academic Sitz im Leben, in which Vico is summoned to dialogue, they in fact constitute his historical opening to the present. ${ }^{6}$

(7) What aspects of the Vichian issue under examination must be rearticulated in modern terms before a fruitful encounter can take place?

Like all seminal thinkers who can claim rightful entry into the eternal contemporaneity of philosophical relevance, Vico is both anchored to and transcends the cultural co-ordinates of his Sitz im Leben. He transcends them in so far as he brought his science to bear on some primordial questions of the philosophy of man in history; and he is anchored to them in so far as his thinking and language acquired their characteristic determinateness in interaction with the cultural life of his age. Consequently, some aspects of his philosophy, being as they are responses to a variety of historical stimuli, cannot claim to be meaningful and normative beyond those co-ordinates in their original form. Thus his use of the language of the humoralist tradition-as in his letter to Gherardo degli Angioli of 26 December 1725 - in order to define basic psychological types that they subsume has clearly some challenging implications for our concern with the psychology of artistic creation and the progress of literary history. Similarly, his diatribe against the Port-Royal educators is only of archeological interest to us, but his rejection of all forms of rationalism, viewed in the context of Grassi's rehabilitation of the humanist tradition, has clear implications for the development of current philosophy. Most students who read Vico have smatterings of Chomsky and have some familiarity not only with the technical aspects of his theory of syntax but with its Port-Royalist philosophical roots. The principle that motivated Vico to reject Port Royal rationalism is a truth that transcends the historicity of 
its articulation if it is a hermeneutically separated from it. In other words, understanding as appropriation must be preceded in such cases by the separation of what is exclusively eighteenth-century material, an expression of the language (in the widest sense of the term) and cultural stimuli of the time, from the concepts that such material manifests and can be transcended by. The issue is not unlike the one faced by Vico himself when he sought to separate the certum of the law, or the literally expressed will to act in a given way, from its ierum, which is the philosophical principle that informs that will, or the spirit of the law that transcend the circumscription of its letter. Clearly only the spirit can have challenging implications for the selfunderstanding of a later age. The pedagogical task is thus resolved into a hermeneutical process analogous to Bultmannian demytholigisation, ${ }^{7}$ into an act, that is, that abstracts principles from the historically conditioned philological form they have in texts and rearticulates them through such modern thought forms and vocabulary as can come to us from philosophy, linguistics, semiotics and hermeneutics. However, it must be clearly understood that this is not a superimposition of modern concepts on Vico, but their instrumental use in the effort to bring out the implications that Vico's thought can have for us today.

These seven exercises, ideally carried out - though with varying degrees of emphasis - in every class of a syllabus based on the topical distribution of Vico's philosophy in a two semester programme, comprise the model that I would propose to those readers of Quaderni ditalianistica who are institutionally able to offer a course on his philosophy. It is a model that aims at the recovery of Vico without subjecting him to compromising assimilations. Sceptics may here recall a famous paper by Pietro Piovani, who, in 1969, at the beginning of the international revival of Vico studies to which the current North American interest in his philosophy owes its existence, outlined with clarity and authority the tasks of Vico scholarship for the last decades of this century. In that paper Piovani issued a warning to the effect that those admirers of Vico who understand their philosophical relations to him as one of spiritual filiation must proceed with great caution if they are not to turn him into a vehicle of "discorsi non suoi" (93). The risk is clcarly there, and it is of daunting magnitude, but it must not become the limit of our thinking. The point of the association of Vico to modern thought is to look for mutual reinforcement and clarification and not to conceal tension and to force assimilation. It is a task that must be approached with great respect for both the responsibility of our own intelligence and the integrity of Vico's thought. The purpose of modern terms, distinctions, and comparisons is not to superimpose our world on his but to draw out more clearly the implications and significance that his thought has for us today. 


\section{NOTES}

1 As recently as 1983 Tagliacozzo observed that there were "still practically no courses on Vico in colleges or universities" (111).

2 For a detailed treatment of North American Vichianism see my article.

$3 \mathrm{I}$ am thinking especially of White.

4 The basic text in this connection is Gadamer.

5 See his preface to Vico: Past and Present ix-x, and my analysis of the question (Pietropaolo 265-68).

6 For the hermeneutical significance of this concept, see Buss.

7 The texts by Rudolf Bultmann that 1 have here in mind are: "The Problems of Hermeneutics," and "The Case for Demytholigization," in Bultmann and Jasper-1 cite this edition, rather than the more standard ones in English, because it contains Karl Jasper's critique of Bultmann's method. On Bultmannian hermeneutics see also McKnight 65-71, and Mazzeo 129-154.

\section{WORKS CITED}

Bultmann, Rudolf. "The Problems of Hermeneutics." Essays Philosophical and Theological. Trans. J. C. G. Greig. London and New York: Macmillan, 1955.

Bultmann, Rudolf, and Karl Jasper. Myth and Christianity. New York: Noonday Press, 1958.

Buss, M. J. "The Idea of Sitz-im-Leben: History and Critique." Zeitschrift für Alttestamentliche Wissenschaft 90 (1978): 157-70.

Chomsky, Noam. Cartesian Linguistics; A Chapter in the History of Rationalist Thought. New York and London: Harper and Row, 1966.

Costa, Gustavo. La leggenda dei secoli d'oro nella letteratura italiana. Bari: Laterza, 1972.

"The Orpheus Myth in European Culture from G. J. Vossius to Vico." The

Enlightenment in a Western Mediterranean Context. Ed. Domenico Pietropaolo et al. Toronto: Society for Mediterranean Studies, 1983. 53-64.

"Vico and Marx: Notes on the History of the Concept of Alienation." Vico and Marx: Affinities and Contrasts. Ed. Giorgio Tagliacozzo. Atlantic Highlands, N.J.: Humanities Press, 1983.

Croce, Benedetto. La filosofia di G. B. Vico. Bari: Laterza, 1973.

Gadamer, Hans Georg. Truth and Method. Trans. G. Barden and J. Cumming. New York: Crossroad Publishing Company, 1982.

Garin, Eugenio. "Le citazioni di Vico." Giornale critico della filosofia italiana 5th ser. 1.3 (1981): 380-86.

Grassi, Ernesto. Heidegger and the Question of Renaissance Humanism. Binghampton: Center for Medieval and Early Renaissance Studies, 1983.

Rhetoric as Philosophy. University Park: The Pennsylvania State UP, 1980.

Jauss, Hans Robert. Acsthetic Experience and Literary Hermeneutics. Trans. M. Shaw. Minneapolis: $\mathrm{U}$ of Minnesota P, 1982.

Mazzeo, Joseph Anthony. Varieties of Interpretation. Notre Dame: U of Notre Dame P, 1978.

McKnight, Edgar V. Mcaning in Texts. Philadelphia: Fortress Press, 1978.

Momigliano, Arnaldo. "La nuova storia romana di G. B. Vico." Rivista storica italiana 77.4 (1965) 773-90.

Nicolini, Fausto. Commento storico alla seconda Scienza nuova. Roma: Edizioni di storia e letteratura, 1949. Rpt. 1978.

Pietropaolo, Domenico. "Premesse e metodi degli studi vichiani in America." Belfagor 41.3 (1986): 263-77.

Piovani, Pictro. "Per gli studi vichiani." Archivio di filosofia (1969): 69-95.

Rossi, Paolo. "Chi sono i contemporanei di Vico?" Rivista di filosofia 71.1 (1981): 51-82.

Tagliacozzo, Giorgio. "Vico and Marx: One Hundred Years After Marx's Death." Rivista di studi italiani 1.1 (1983): 98-121. 
cd. Vico: Pass and Prese'm. Allantic llighlands, N.J.: Humanitics Press, 1981.

Tagliacozzo, Giorgio, and Hayden White, eds. Giambatrisa lices: An Internutional Simposum. Baltimore: The Johns Hopkins UP, 1969.

Tagliacozzo, Giorgio, Donald Phillip Verenc, and Vanessa Rumble, eds. Bibloggraphy of lico in English. Bowling Green, Ohio: Philosuphy Documentation Center, 1986.

Valdes, Mario J. Phenomenological Ilermenemucs and the Sudv of liferature. Toronto: $U$ of Toronto P, 1987.

White, Hayden. Metahiseory Ballimore: The John Hopkins UP, 1978. 